\title{
No Zero Sum in Opioids for Chronic Pain: Neurostimulation and the Goal of Opioid Sparing, Not Opioid Eradication
}

\author{
Michael E Schatman (D) ${ }^{1-3}$ \\ Erika A Petersen (iD) 4 \\ Dawood Sayed (iD ${ }^{5}$ \\ 'Department of Diagnostic Sciences, \\ Tufts University School of Dental \\ Medicine, Boston, MA, USA; \\ ${ }^{2}$ Department of Public Health and \\ Community Medicine, Tufts University \\ School of Medicine, Boston, MA, USA; \\ ${ }^{3}$ School of Social Work, North Carolina \\ State University, Raleigh, NC, USA; \\ ${ }^{4}$ Department of Neurosurgery, \\ University of Arkansas for Medical \\ Sciences, Little Rock, AR, USA; \\ ${ }^{5}$ Department of Anesthesiology and Pain \\ Medicine, The University of Kansas \\ Medical Center, Kansas City, KS, USA
}

Correspondence: Michael E Schatman $\mathrm{Tel}+$ I 425-647-4880

Email Michael.Schatman@tufts.edu
In 1967, Dr Norm Shealy and his colleagues reported on the first spinal cord stimulator (SCS) for dorsal stimulation. ${ }^{1}$ Unfortunately, the patient succumbed to undiagnosed bacterial endocarditis 6 days following the onset of stimulation. Irrespective, the first patent for spinal cord stimulation was granted in $1968 .^{2}$ The first fully implantable SCS system was provided in 1981, with the first rechargeable system developed and released in $2004 .^{2}$

Subsequently, the use of SCS to treat neuropathic pain has gained progressive popularity. Initially, strong evidence was rare, ${ }^{3,4}$ many systematic reviews failed to establish strong supporting evidence, and there were numerous complications associated with the large and cumbersome units that were utilized for decades. ${ }^{5-7}$ As the technology (and perhaps identification of appropriate patient candidates and technical expertise of interventionalists and surgeons) improved, the evidence-basis of SCS assessed via systematic reviews began to improve in the latter part of the first decade of this millennium. ${ }^{8,9}$

The demonstrated efficacy of neuromodulation for neuropathic pain conditions increased dramatically over the past decade as the quantity and caliber of published clinical results burgeoned. With the advent of new technologies such as highfrequency, burst SCS, and dorsal root ganglion stimulation - all of which provide advantages to the low-frequency, tonic stimulation that was provided by older units - further improvements in outcomes were reported. Not only do the newer units provide paresthesia-free or minimal-paresthesia analgesia, but they have been demonstrated through myriad systematic reviews to be safe, clinically effective, and even cost-effective in treating neuropathic pain of axial spine or radicular origin, as well as radicular symptoms, in addition to other types of neuropathic pain across different populations. ${ }^{10-22}$

While SCS has been a treatment option for chronic pain for only half a century, accounts of the use of opioids date back to at least $1550 \mathrm{BC}$, when an ancient Egyptian pharmacopoeia contained prescriptions for uses of opium. ${ }^{23}$ Although effective as analgesics for many types of pain, opioids' efficacy for neuropathic pain has been determined to be extremely limited, at best. ${ }^{24-28}$ Additionally, systematic reviews point to issues of tolerability, ${ }^{29}$ and adverse effects including, but not limited to, constipation, ${ }^{30}$ cognitive dysfunction, ${ }^{31}$ endocrinopathy, ${ }^{32}$ mood disturbance, ${ }^{33}$ and sleep apnea. ${ }^{34}$ Although some studies have attempted to 
demonstrate a causative relationship between opioid use and substance use disorders in chronic pain patients, variance in definitions and a prevalence of methodologically flawed studies based upon investigator bias make such a conclusion tenuous.

Although the past several years have witnessed a war on prescription opioids in the United States and on those who prescribe them, ${ }^{35}$ clinicians involved in the care of chronic pain patients understand that a multimodal approach which might include prescription opioids is still a safe and reasonable avenue when the appropriate precautions are taken. ${ }^{36-39}$ The individual clinical circumstance of each patient should allow for a personalized pain treatment strategy. While some appear to be focused on the eradication of opioids for chronic pain, the rational and ethical approach in light of the inability of many to access safer and more effective treatments is "opioid-sparing" rather than "opioid eradication". 40 SCS has been demonstrated to be opioid-sparing. A 2019 systematic review, ${ }^{41}$ for example, determined that in patients with chronic spine/limb pain, SCS was associated with an increased likelihood of decreasing consumption of pain medications. Only extremists on both sides of the opioid argument would reject the benefits of patient-centered opioidsparing approaches such as SCS, which brings us to social media. Recently, we have seen a rash of posts (from anonymous accounts and some presumed to be from physicians who have lost their medical licenses and/or controlled substance licenses due to illegal and/or irresponsible opioid prescribing) suggesting that opioids are the only effective and viable treatment for chronic pain. In order to "prove" their disingenuous point, they are progressively painting a false narrative of the "evils" of all other treatments, eg, hyperbolically stating that any utilization of acetaminophen, even in a single instance, will result in grave hepatic injury. Recently, we have observed false claims regarding the lack of efficacy and safety of SCS disseminated across social media, inaccurately claiming that "most" patients who undergo implantation either "die" from infections or surgical errors or require that their units are explanted secondary to a lack of efficacy and dramatic increases in pain levels. Despite the demise of Dr Shealy's unfortunate patient in 1967, the empirical data, as well as our 65 years of collective experience in working with SCS, clearly belie these disingenuous claims that SCS is anything but safe and effective.

From an ethical perspective, we are concerned that social media postings from unverified sources such as (expracticing) physicians may undermine the evidencesupported approach of multimodal chronic pain treatment.
Because these agents preach that only opioids are effective for chronic pain and that all other treatments are dangerous shams, vulnerable chronic pain patients desperate for relief might buy into false narratives, and, as a result, reject recommendations to consider SCS and other non-opioid pain management strategies. We recognize that neurostimulation is hardly a panacea for all patients with intractable chronic neuropathic pain, yet our experience and the research cited above strongly suggests that this neuromodulation approach can safely provide analgesia, improve function, enhance emotional functioning, and result in improved quality of lives. Opioid-sparing is an ethical and rational approach to chronic pain, and SCS can contribute to this goal. Until these online statements can be substantiated with appropriate data and the motives, conflicts of interest, and objectives of their purveyors can be clearly understood, the claims should be taken with great caution. Accordingly, patients should seek out reliable sources for medical information over the claims disseminated through social media. Our hope is that those who are greatly concerned with the treatment of chronic pain - patients, their loved ones and their treatment teams will regard this editorial and begin to understand the level of potential harm being caused by these radically pro-opioid physicians, who should be honest and intelligent enough not to disregard the science. No one treatment is a solution for the complexity of chronic pain, and the motives of anyone who advocates for a non-negotiable solitary solution without nuance or individualization should be critically evaluated.

\section{Disclosure}

Dr Michael E Schatman is a research consultant for Modoscript, outside the submitted work. Dr Petersen has received research support from Medtronic, Neuros Medical, Nevro Corp, ReNeuron and Saluda, as well as personal fees from Abbott Neuromodulation, Medtronic Neuromodulation, Neuros Medica, Nevro, and Vertos. She holds stock options from SynerFuse. Dr Dawood Sayed reports personal fees from Abbott, Medtronic, Nevro, during the conduct of the study. The authors report no other conflicts of interest in this work.

\section{References}

1. Shealy CN, Mortimer JT, Reswick JB. Electrical inhibition of pain by stimulation of the dorsal columns: preliminary clinical report. Anesth Analg. 1967;46(4):489-491. doi:10.1213/00000539-196707000-00025

2. Kumar K, Rizvi S. Historical and present state of neuromodulation in chronic pain. Curr Pain Headache Rep. 2014;18(1):387.

3. Bell GK, Kidd D, North RB. Cost-effectiveness analysis of spinal cord stimulation in treatment of failed back surgery syndrome. $J$ Pain Symptom Manage. 1997;13(5):286-295. 
4. Kumar K, North R, Taylor R, et al. Spinal cord stimulation vs. conventional medical management: a prospective, randomized, controlled, multicenter study of patients with failed back surgery syndrome (PROCESS Study). Neuromodulation. 2005;8(4):213-218.

5. McQuay HJ, Moore RA, Eccleston C, Morley S, Williams AC. Systematic review of outpatient services for chronic pain control. Health Technol Assess. 1997;1(6):i-iv, 1-135.

6. Mailis-Gagnon A, Furlan AD, Sandoval JA, Taylor R. Spinal cord stimulation for chronic pain. Cochrane Database Syst Rev. 2004;3:CD003783.

7. Turner JA, Loeser JD, Deyo RA, Sanders SB. Spinal cord stimulation for patients with failed back surgery syndrome or complex regional pain syndrome: a systematic review of effectiveness and complications. Pain. 2004;108(1-2):137-147.

8. Taylor RS. Spinal cord stimulation in complex regional pain syndrome and refractory neuropathic back and leg pain/failed back surgery syndrome: results of a systematic review and meta-analysis. J Pain Symptom Manage. 2006;31(4 Suppl):S13-19.

9. Simpson EL, Duenas A, Holmes MW, Papaioannou D, Chilcott J. Spinal cord stimulation for chronic pain of neuropathic or ischaemic origin: systematic review and economic evaluation. Health Technol Assess. 2009;13(17):iii,ix-x, 1-154.

10. Hou S, Kemp K, Grabois M. A systematic evaluation of burst spinal cord stimulation for chronic back and limb pain. Neuromodulation. 2016;19(4):398-405.

11. Kapural L, Peterson E, Provenzano DA, Staats P. Clinical evidence for spinal cord stimulation for failed back surgery syndrome (FBSS): systematic review. Spine (Phila Pa 1976). 2017;42(Suppl 14):S61-S66.

12. Moens M, Goudman L, Brouns R, et al. Return to work of patients treated with spinal cord stimulation for chronic pain: a systematic review and meta-analysis. Neuromodulation. 2019;22(3):253-261.

13. Chakravarthy K, Malayil R, Kirketeig T, Deer T. Burst spinal cord stimulation: a systematic review and pooled analysis of real-world evidence and outcomes data. Pain Med. 2019;20(Suppl 1):S47-S57.

14. Hofmeister M, Memedovich A, Brown S, et al. Effectiveness of neurostimulation technologies for the management of chronic pain: a systematic review. Neuromodulation. 2020;23(2):150-157.

15. Ontario Health (Quality). 10-kHz high-frequency spinal cord stimulation for adults with chronic noncancer pain: a health technology assessment. Ont Health Technol Assess Ser. 2020;20(6):1-109.

16. Niyomsri S, Duarte RV, Eldabe S, et al. A systematic review of economic evaluations reporting the cost-effectiveness of spinal cord stimulation. Value Health. 2020;23(5):656-665.

17. Liampas A, Rekatsina M, Vadalouca A, Paladini A, Varrassi G, Zis P. Non-pharmacological management of painful peripheral neuropathies: a systematic review. Adv Ther. 2020;37(10):4096-4106.

18. Vallejo R, Gupta A, Cedeno DL, et al. Clinical effectiveness and mechanism of action of spinal cord stimulation for treating chronic low back and lower extremity pain: a systematic review. Curr Pain Headache Rep. 2020;24(11):70.

19. Galafassi GZ, Simm Pires de Aguiar PH, Simm RF, et al. Neuromodulation for medically refractory neuropathic pain: spinal cord stimulation, deep brain stimulation, motor cortex stimulation, and posterior insula stimulation. World Neurosurg. 2021;146:246-260.

20. Karri J, Palmer JS, Charnay A, et al. Utility of electrical neuromodulation for treating chronic pain syndromes in the pediatric setting: a systematic review. Neuromodulation. 2021;8. doi:10.1111/ner.13365

21. Duarte RV, Nevitt S, Maden M, et al. Spinal cord stimulation for the management of painful diabetic neuropathy: a systematic review and meta-analysis of individual patient and aggregate data. Pain. 2021. doi:10.1097/j.pain.0000000000002262

22. McClure JJ, Desai BD, Ampie L, You W, Smith JS, Buchholz AL. A systematic review of the cost-utility of spinal cord stimulation for persistent low back pain in patients with failed back surgery syndrome. Global Spine J. 2021;11(1_suppl):66S-72S.
23. Papyrus E. Das Hermetische Buch Über Die Arzneimittel Der Alten Aegypter Von Georg Ebers. Leipzig: Engelmann; 1875.

24. Gaskell H, Moore RA, Derry S, Stannard C. Oxycodone for neuropathic pain and fibromyalgia in adults. Cochrane Database Syst Rev. 2014;6:CD010692.

25. Welsch P, Sommer C, Schiltenwolf M, Häuser W. [Opioids in chronic noncancer pain-are opioids superior to nonopioid analgesics? A systematic review and meta-analysis of efficacy, tolerability and safety in randomized head-to-head comparisons of opioids versus nonopioid analgesics of at least four week's duration]. Schmerz. 2015;29(1):85-95. German.

26. Gaskell H, Derry S, Stannard C, Moore RA. Oxycodone for neuropathic pain in adults. Cochrane Database Syst Rev. 2016;7(7):CD010692.

27. McNicol ED, Ferguson MC, Schumann R. Methadone for neuropathic pain in adults. Cochrane Database Syst Rev. 2017;5(5):CD012499.

28. Bialas P, Maier C, Klose P, Häuser W. Efficacy and harms of longterm opioid therapy in chronic non-cancer pain: systematic review and meta-analysis of open-label extension trials with a study duration $\geq 26$ weeks. Eur J Pain. 2020;24(2):265-278.

29. Sommer C, Welsch P, Klose P, Schaefert R, Petzke F, Häuser W. [Opioids in chronic neuropathic pain. A systematic review and meta-analysis of efficacy, tolerability and safety in randomized placebo-controlled studies of at least 4 weeks duration]. Schmerz. 2015;29(1):35-46. German.

30. Whittle SL, Richards BL, Husni E, Buchbinder R. Opioid therapy for treating rheumatoid arthritis pain. Cochrane Database Syst Rev. 2011;11:CD003113.

31. Tannenbaum C, Paquette A, Hilmer S, Holroyd-Leduc J, Carnahan R. A systematic review of amnestic and non-amnestic mild cognitive impairment induced by anticholinergic, antihistamine, GABAergic and opioid drugs. Drugs Aging. 2012;29(8):639-658.

32. De Vries F, Bruin M, Lobatto DJ, et al. Opioids and their endocrine effects: a systematic review and meta-analysis. J Clin Endocrinol Metab. 2019;105(3):1020-1029.

33. Wehbeh L, Dobs AS. Opioids and the Hypothalamic-PituitaryGonadal (HPG) axis. J Clin Endocrinol Metab. 2020;105(9):dgaa417.

34. Mubashir T, Nagappa M, Esfahanian N, et al. Prevalence of sleep-disordered breathing in opioid users with chronic pain: a systematic review and meta-analysis. J Clin Sleep Med. 2020;16 (6):961-969.

35. Atkinson TJ, Schatman ME, Fudin J. The damage done by the war on opioids: the pendulum has swung too far. $J$ Pain Res. 2014;7:265-268.

36. Lagisetty PA, Healy N, Garpestad C, Jannausch M, Tipirneni R, Bohnert ASB. Access to primary care clinics for patients with chronic pain receiving opioids. JAMA Netw Open. 2019;2(7):e196928.

37. Noori SA, Aiyer R, Yu J, White RS, Mehta N, Gulati A. Nonopioid versus opioid agents for chronic neuropathic pain, rheumatoid arthritis pain, cancer pain and low back pain. Pain Manag. 2019;9 (2):205-216.

38. Brennan MJ, Gudin JA. The prescription opioid conundrum: 21st century solutions to a millennia-long problem. Postgrad Med. 2020;132(1):17-27.

39. Marchetti Calônego MA, Sikandar S, Ferris FD, Moreira de Barros GA. Spread the word: there are two opioid crises! Drugs. 2020;80(12):1147-1154.

40. Mariano ER, Schatman ME. A commonsense patient-centered approach to multimodal analgesia within surgical enhanced recovery protocols. J Pain Res. 2019;12:3461-3466.

41. Pollard EM, Lamer TJ, Moeschler SM, et al. The effect of spinal cord stimulation on pain medication reduction in intractable spine and limb pain: a systematic review of randomized controlled trials and meta-analysis. J Pain Res. 2019;12:1311-1324. 


\section{Publish your work in this journal}

The Journal of Pain Research is an international, peer reviewed, open access, online journal that welcomes laboratory and clinical findings in the fields of pain research and the prevention and management of pain. Original research, reviews, symposium reports, hypothesis formation and commentaries are all considered for publication. The manuscript management system is completely online and includes a very quick and fair peer-review system, which is all easy to use. Visit http:// www.dovepress.com/testimonials.php to read real quotes from published authors. 